\title{
Globalization and Women's Employability in Sub-Saharan Africa
}

\author{
Kossi AYENAGBO ${ }^{1}$ \\ ${ }^{1}$ Department of Economics, University of Kara, LaRSEG/FaSEG, Togo \\ Correspondence: Kossi AYENAGBO, Department of Economics, University of Kara, LaRSEG/FaSEG, Togo.
}

Received: September 6, 2021

Accepted: January 18, $2022 \quad$ Available online: February 3, 2022

doi:10.11114/ijsss.v10i2.5471

URL: https://doi.org/10.11114/ijsss.v10i2.5471

\begin{abstract}
The objective of this paper is to analyze the effects of globalization on female employment in Sub-Saharan Africa (SSA). The GMM estimator was used in the econometric approach based on panel data from 39 Sub-Saharan African countries covering the period from 1995-2018. For further analysis, the sample was divided into four subgroups of regions including Central, Eastern, Western and Southern regions of Sub-Saharan Africa. The estimation results revealed that globalization measured by the openness rate and FDI flows significantly affects women's employment. This effect is positive for the openness rate and negative for FDI. This can be explained by the high representation of women in the informal sector whose main activity is trade. The results also showed a significant effect of socio-economic variables, particularly Gross Domestic Product (GDP). Policymakers, in their efforts to stimulate economic growth, should put in place policies and programs that promote trade liberalization and women's empowerment.
\end{abstract}

Keywords: globalization, women's employment, poverty, sub-saharan Africa, The GMM estimator, panel data

JEL classification codes: C23, E10, E24, O10, O55

\section{Introduction}

Over the past two decades, globalization has had a dramatic effect on the lives of women in developing countries. Globalization can be defined as a complex economic, political, cultural, and geographic process in which the mobility of capital, organizations, ideas, discourses, and people have taken on a global or transnational form (Moghadam, 1999). Economic globalization is defined as an intensification of trade between different economic markets on a global scale. Contemporary economic globalization has emerged as the internationalization of financial and trade flows and the foreign location of firms. Much less attention has been paid to the effects of economic integration on gender inequality. Yet, the evidence suggests that globalization may benefit women (Villareal et al., 2007). In particular, research on development economics indicated that international trade increased women's employment in less developed countries (Braunstein, 2006).

For example, women's participation in the labor force has increased dramatically in developing countries over the past few decades. While the proportion of employed women in developing countries, particularly in Sub-Saharan Africa, was lower than in more developed countries. Recent estimates indicated that women's labor force participation rates are higher in Sub-Saharan African countries than in other regions of the world. For example, according to World Bank statistics, the employability rate for women is estimated in 2018 to be $46 \%$ of the population in Sub-Saharan Africa, while it is about $41 \%$ in Latin America and $43 \%$ in the Organisation for Economic Co-operation and Development (OECD) countries (WDI, 2019). According to information from the International Labor Organization (ILO), women's employment has grown faster than men's since 1980 in most regions of the world. Factors such as women's higher educational attainment and lower fertility rates, as well as changing attitudes toward women working outside the home, are increasing women's employment rates by increasing the supply of female labor (Chant and Craske, 2003).

In these countries, some types of work, such as garment assembly, are seen as an extension of women's roles in the household. For Braunstein (2006), the fundamental reason that export production increases the demand for female labor is that women are a cheaper source of labor. An increased demand for low-skilled labor thus increases the demand for women, all else being equal. Therefore, cultural influences in developing countries also have an impact on employment stratification. The high demand for employment opportunities for women in developing countries leads to an instantaneous change in the social organization of these societies. An investigation of the importance of globalization in 
the economic participation of women in Africa is all the more relevant given that unemployment is one of the most challenging current and future political syndromes on the continent. As a result, the contemporary world is experiencing the most significant population growth and Africa is at the center of this challenge. Given the apparent discrimination against women in Africa (Elu and Loubert, 2013; Osabuohien et al, 2019), unemployment should logically be more apparent among women.

The adoption of Structural Adjustment Programs (SAPs) in 1980 and the subsequent economic and financial crisis of 2008 had a severe impact on the labor market in the African world. The sudden slowdown in economic activity led to a rapid and massive rise in unemployment. In addition to these crises, which have affected social sectors, particularly employment, there was the recent global health crisis caused by Covid-19, which led to the adoption of response measures, including the containment and closure of some activities centers. Thus, the current crisis has focused on some sectors of activity, notably markets, hotels and restaurants, sectors in which women are particularly present. This explained the gendered nature of the effects of this crisis on employment. The analysis of its impact from a gender perspective questions more broadly our societal organization which, despite the advances of recent decades, remains fixed on a gendered division of labor that constitutes an obstacle to equality between women and men.

The purpose of this article is therefore to analyze the effect of globalization on women's employability in the context of Sub-Saharan African countries. This paper adds to the empirical literature on the effect of globalization on women's employability in Sub-Saharan Africa where studies have focused more on the effect of globalization on economic growth. In our analysis, we will briefly reviewed the literature on the effect of globalization on women, followed by the methodology that will allowed us to the results obtained, the discussions and eventually the conclusion and policy implications.

\section{Literature Review}

\subsection{Theoretical Review}

Classical theory has long emphasized that an abundance of labor is essential for increasing productivity. Becker (1964) introduced the notion of human capital, allowing labor to be treated as a factor of production that can be accumulated in the same way as capital goods. Labor productivity and, in turn, wages can be significantly improved by investments that increase skills and abilities. Investments can be considered by the worker who decides to delay entry into the labor market to increase future earnings, or by the employer who wishes to improve productivity and funds a training program, since training expenditures are considered by economists to be intangible investment expenditures. Thus, the investment will occurred whenever the expected gain exceeds the cost of the training (Schultz, 1961).

This work makes it possible to justify wage differentials and partly explained poverty phenomena, because not all individuals have the same financial means to invest in their own human capital, given that other inequalities reinforce this disparity, such as social relations or the socio-cultural environment. Under these conditions, wages are no longer the only determinant of labor supply and demand. Rational behavior can lead to staying out of the labor market for a while, since the economic calculation is based on expectations of probable gains. For his part, George Stigler in 1962 introduced into the study of labor markets the absence of market transparency. Since contractors do not know everything about the characteristics of supply and demand, they are led to seek additional information. They will carry out an economic calculation by constrained optimization, taking into account this search for information since it has a cost. Many authors have developed this analysis, which has long been called "job-search theory" for employees and employers, because the problems are the same for both categories of actors (Faggian, 2014). Job-search takes time because the market is not transparent. The unemployed person will search for the optimal search time, comparing the marginal gain of prolonging the job search and the marginal cost of gathering information.

Later, in 1981, Okun offered a systematic exposition of the earlier work with particular emphasis on the notion of reservation or reservation wages (Rioux, 2001; Stephan, 2014). The reservation wage is the wage below which the worker refuses to work. The reservation wage is strongly determined by three elements namely:

-Subjective knowledge of the wage distribution in the market ;

-The time spent searching for a job with a wage higher than the reservation wage;

-The cost of job search.

The analysis of market dualism showed that the primary labor market is characterized by jobs that require substantial training and have a high degree of responsibility and independence (Zajdela, 1990). In this primary market, wages are set above the level of the prevailing wage and follow the logic of efficiency. Jobs are therefore rationed and employees are in a position of strength. However, the secondary labor market is competitive. Jobs are more precarious and wages are lower. Turnover costs are low, and wages followed the market logic of supply and demand. If we assume that market segmentation is strong, then, there is no transition from one market to the other without unemployment. 


\subsection{Empirical Review}

According to Asongu (2020), there are three main strands of contemporary development literature that motivated research on the effect of globalization on women's employability :(i) the low participation of the female gender in the labor market; (ii) the contemporary relevance of making globalization more inclusive and (iii) the challenges of sustainable development in terms of employment and inclusive development in Africa.

The contradictory nature of the relationship between globalization and women's oppression is most evident in Third World economies. Indeed, beyond the diversity of societies and situations, it can be noted that the upheavals due to globalization occurred following development strategies which, in the 1950s to 1970s, totally ignored the place of women, particularly in agriculture, where training projects or agrarian reforms were aimed only at heads of family or heads of household. These developments also contributed to destabilizing social structures which, far from representing an "original" state of societies, insofar as they had been largely transformed by colonization and reshaped by capitalism, nonetheless used the argument of tradition to justify various forms of maintaining women's subordination in the family or community.

Over the past decade, almost everywhere in the world, there has been an increase in the labor force participation rate of women, including in developing countries where it was traditionally low, such as Sub-Saharan Africa (WDI, 2019) (Talahite, 1998). This growth in the labor force participation rate, both in the wage and informal sectors, is largely driven by foreign direct investment flows into export industries (Treillet, 1999). Several studies, notably the one carried out by Gedisst on the paradoxes of globalization have noted an increase in salaried employment opportunities in skilled industrial fields for women in some Asian and Latin American countries (Hirata, Le Doaré 1998). But this new reality is contradictory, even in jobs related to new technologies such as computers and electronics, which are not limited to assembly activities. Women are entrusted with the worst maintenance services. Trade liberalization in various countries, especially in Latin America, has caused the collapse of many industries that were previously protected by tariff barriers and that employed mostly men, even though the export labor industries first hired women. The women employed in these industries accumulate all the aspects of the worst kind of overexploitation, notably the absence of labor rights and trade union freedom, very long and flexible working hours, unhealthy and often dangerous working conditions, not to mention gender-based violence, harassment, and control over their private lives.

We can also observed contradictory effects of the extension of individual property rights to land in Africa and Mexico with the reform of the ejido (Katz, 1999). Indeed, this evolution, whose overall, negative consequences have already been seen, sometimes calls into question some rights specific to women that were guaranteed by custom, but always subordinated to the goodwill of men or male community authorities. The same contradictory aspect can be found in situations of economic and social crisis. For example, a study of the consequences of the 1997-1998 Asian crisis in the Philippines (Lim, 2000) showed that the crisis resulted in a general impoverishment of the population, an increase in the number of paid and unpaid working hours for women compared to men, and an increase in the number of women working in the informal sector, but also an increase in male unemployment that was faster than that of women, due to the segregation of the labor market, which over-represents women in the informal sector and in service or trade jobs, which were less affected by the crisis.

The low participation of women in the formal economic sectors, while women have traditionally been the most vulnerable group in the labor market, this vulnerability is comparatively more relevant in Africa (Efobi et al., 2018). Women are mostly absorbed into the informal economic sectors, including engaging in small-scale sole proprietorship and smallholder farming (Uduji and Okolo-Obasi, 2019a, 2019b; Asongu and Odhiambo, 2018, 2019). In addition, there is an evolving literature on the pervasiveness of women's labor representation (Marquez, 2017 ; Luo et al., 2017 ; Moras, 2017 ; Rice and Barth, 2017 ; Uduji and Okolo- Obasi, 2018).

The concern for women's economic participation in Sub-Saharan Africa (SSA) relative to other regions of the world is based on scientific evidence that women in this region are the poorest in the world largely due to women's exclusion in many activities (Hazel, 2010 ; Efobi et al., 2018). In addition, a recent report by the World Bank, estimated that the loss of income from women's exclusion in the region will be approximately US $\$ 2.5$ billion (Nkurunziza, 2018).

Economic arguments about the effects of globalization on women fall into two main groups, one highly critical and the other fundamentally optimistic, but with caveats (Gray, 2006). From the critical perspective, economic globalization has largely negative consequences for women. Globalization confined women to low-paying, low-status, often part-time jobs that reinforce their subordination and allowed the devaluation of women's work in most societies. The demand of multinationals for cheap, flexible labor has encouraged offshore production using low-paid women.

Women, however, remain excluded from the more stable and better paid jobs in heavy industry. Globalization is leading to an increasing feminization of labor, as women continue to be seen as dependents and thus confined to lower-paying jobs (Villarreal and $\mathrm{Yu}, 2007$ ). The removal of barriers to transnational investment, far from empowering women, has 
provided them with dismal jobs in offshore production sites where women face discrimination and sexual harassment. In addition, competition from foreign companies undermines efforts to help women start local micro-enterprises. Some women may benefit from new jobs, but their work is highly exploitative and characterized by low wages, poor working conditions, suppression of unions, and few opportunities for security or advancement (Gray, 2006).

In addition, the Structural Adjustment Policies and market liberalization that have accompanied globalization are particularly detrimental to women. These policies lead to reductions in public sector jobs that are often disproportionately held by women, undermined social programs that benefit women, and hinder women's work organization (Asongu et al., 2020). Another argument is that industrial development caused environmental damage that partly degrades the lives of women in developing countries. Women, suffer the most from environmental problems because they are responsible for most of the family or household's livelihood and it is harder for them to find food and fuel, and their diets suffer (Parida, 2011). Globalization, including greater openness to foreign direct investment (FDI), has led to a massive infusion of women into labor markets. Particularly in low-income countries, foreign multinationals often make better paying jobs available to women.

However, with globalization, more women have more options for gainful employment. More job opportunities mean more ways out of unequal relationships and these options give women more chances to take their work and skills elsewhere. According to Gray (2006), with regular wage work, women gain greater personal autonomy and independence. They have more control over budgeting and other household decisions. As a result, they have more leverage to ask men for help with domestic tasks. As households become more dependent on women's income, women's status and relative power improve. The economic changes associated with globalization may also provide the seeds for cultural transformations that improve the status of women.

To the extent that economic globalization expands women's work opportunities and increases their independent incomes, it improves their well-being and provides them with additional options within their households and in social life. We hypothesize that trade and FDI will have different effects for women. To the extent that trade enhances economic growth in general, it will improve the physical quality of life, as measured by life expectancy and literacy. But trade may also displace employment in local industries, reducing employment opportunities for women. In contrast, FDI is more likely to create new jobs, many of which will be available to women. Certainly, women often retained the bulk of unpaid domestic work. This creates a double burden. In addition, depending on the cultural, social and family context, not all women will benefit from paid employment. However, it is important to note that independent economic resources and opportunities give women more choices and the chance to pursue their collective interests.

\section{Methodology}

\subsection{Data Sources}

The majority of the data comes from the World Bank's database (WDI). We have defined a sample of 39 Sub-Saharan African countries for which we will use annual observations from 1995 to 2018.

\subsection{Specification of the Analysis Model}

Based on the existing literature on the impact of globalization on women's employability (Asongu et al., 2020 ; Villarreal and $\mathrm{Yu}, 2007)$, we can formulate the following broad empirical formulation :

$$
E m p=f(\text { Mond }, G D P, X)
$$

The variable Emp represents the employability of women as measured by the proportion of women in the labor force ; the variable Mond represents the indicator of globalization as measured by the rate of Trade Openness (TO) and Foreign Direct Investment (FDI); GDP is the Gross Domestic output Per Capita, while $\mathbf{X}$ represents a set of socioeconomic characteristics.

The analytical approach is based on a panel data model that covers 39 Sub-Saharan African countries from 1995 to 2018. As a result, equation (1) is written as follows :

$$
E m p_{i t=} \beta_{i}+\beta_{1 \text { Mond }_{i t}}+\beta_{2} G P D_{i t} \quad+\beta_{3} P O P_{15-64 i t}+\beta_{4} U_{r b} b_{i t}+\beta_{5} \text { Fert }_{i t}+\varepsilon_{i t}
$$

Where $\beta_{i}$ represents the influence that is unique to each country; $\mathbf{i}$ and $\mathbf{t}$ represent respectively the number of individuals (country) and the time period (year); because the amount of growth might lead to a widening of the market and hence more employment prospects (Thévenon, 2004), thus, GDP is the gross domestic product per capita in US dollars; because a young population is more likely to find opportunities in the job market, thus, POP15-64 represents the population of women aged 14 to 64 years as a percentage of the total female population (Pacaut et al., 2007); Urb represents the female fertility rate as measured by the number of births per woman, and Fert represents the urbanization rate as measured by 
urban population since it leads to a larger market and hence greater opportunities (Lachaud, 2009). (Edon and Komionka, 2011).

The descriptive data around the variables revealed a discrepancy in women's employment rates among Sub-Saharan African countries. The female employability rate varies by around $5.9 \%$ of the population from one country to the next, with the minimum and greatest rates estimated at $27 \%$ and $56 \%$ of the population, respectively, across the time. The openness rate varies by roughly $28 \%$ from one country to the next, while FDI varies by about $5 \%$ of GDP. Table 1 below showed the statistics for the other variables.

Table 1. Descriptive statistics of variables

\begin{tabular}{|c|c|c|c|c|c|}
\hline Variable & Observation & average & $\begin{array}{l}\text { Standard } \\
\text { deviation }\end{array}$ & Minimum & Maximum \\
\hline Employment & 936 & 45.405 & 5.856 & 26.976 & 55.833 \\
\hline Opening rate & 930 & 65.291 & 28.023 & 14.772 & 175.798 \\
\hline FDI & 936 & 3.336 & 5.117 & -8.703 & 46.275 \\
\hline GDP & 936 & 1504.296 & 1931.208 & 102.598 & 11208.34 \\
\hline Fertility & 936 & 5.114 & 1.253 & 1.36 & 7.725 \\
\hline Urbanization & 936 & 37.569 & 15.595 & 7.211 & 89.37 \\
\hline Population 15-64 & 936 & 54.183 & 4.047 & 47.703 & 70.104 \\
\hline
\end{tabular}

Source : Author, construction based on data from WDI (2019).

\subsection{Estimation Technique}

The operational model of equation (2) can thus be rewritten in its dynamic form as follows:

$$
E m p_{i t=} \beta_{i}+\beta_{1} E_{m p} p_{i t-1}+\beta_{2 \text { Mond }_{i t}}+\beta_{3} G P D_{i t} \quad+\beta_{4} P O P_{15-64 i t}+\beta_{5} \text { Urb }_{i t}+\beta_{6} \text { Fert }_{i t}+\varepsilon_{i t}
$$

$E m p_{i t-1}$ represents the women's employability lagged variable

The generalized method of moments (GMM) estimator was used to compensate for possible endogeneity biases that may occur in the model. The adoption of the GMM estimator, according to Arellano and Bond (1991), mitigated the endogeneity problem with the explanatory variables. To compensate for endogeneity, the GMM method involved postponing the variables by one or two periods, and these delayed variables also function as instruments. The benefits of using such an estimator are numerous. On one side, it allowed the dependent variable to be delayed by two periods as instruments of the explanatory variable, and on the other hand, it allowed the variable to be delayed by more than two periods, preventing correlation with the error run. Finally, the estimator allowed us to solve the stationarity problem (first difference of the variables) while avoiding the autocorrelation problem on the one hand.

\section{Results and Discussions}

Table 2 showed the findings of the estimates of the impact of globalization on women's employability in Sub-Saharan Africa. The findings revealed that, in general, in SSA, globalization has a considerable impact on women's employment rates (Asongu et al., 2020). However, the results revealed a positive association between trade openness and women's employment rate on the one hand, and a negative relationship between FDI and women's employment rate on the other, when it came to the metrics employed to measure globalization. However, this effect is weak across the board, implying that SSA countries' engagement in trade openness, as well as their efforts in the area of FDI, is limited. The substantial presence of women in the informal sector, whose major activity is trading, can explain the favorable effect of trade openness on women's employment rates. Thus, insofar as trade reinforces economic growth in general, the greater the openness of trade, the more women will have access to opportunities. The internalization of trade could, in this sense, improve women's employability.

Concerning the negative relationship between FDI and female employment, this result may be explained by the fact that women remain excluded from the more stable and better-paying jobs in heavy industry (Gray, 2006). Foreign firms that produce goods for sale in domestic markets (not for export) are more often involved in heavier, capital-intensive industries, such as metallurgy and chemicals, which tend to employ fewer women because the work requires physical strength.

The findings revealed that GDP has a considerable impact on female employment rates. A one percent rise in GDP would result in a 0.08 percent increase in the female labor force. Policymakers may be able to expand public spending on women's empowerment and gender equality projects as a result of high growth (Villareal et al., 2007). The findings also revealed a considerable impact on the employment rate of women between the ages of 15 and 64. Sub-Saharan Africa has a huge young population, the most of whom, particularly women, work in the informal economy. 
Table 2. Results of the estimates of the effect of globalization on the employment rate

\begin{tabular}{lc}
\hline Variables & Estimation by the GMM estimator \\
\hline L.PAF & $0.876^{* * *}$ \\
Trade & $(0.008)$ \\
& $0.001^{*}$ \\
FDI & $(0.001)$ \\
& $-0.003^{*}$ \\
GDP & $(0.002)$ \\
& $0.076^{* * *}$ \\
Pop15-64 women & $(0.021)$ \\
& $0.094^{* * *}$ \\
Urbanization & $(0.011)$ \\
& $0.009 * *$ \\
Fertility & $(0.004)$ \\
Constant & 0.019 \\
& $(0.032)$ \\
Observations & $1.280^{* *}$ \\
Number of Id & $(0.528)$ \\
\hline
\end{tabular}

Standard errors in parentheses

$* * * \mathrm{p}<0.01, * * \mathrm{p}<0.05, * \mathrm{p}<0.1$

Source: Author, construction based on data from WDI (2019)

Table 3 below showed the results of the estimates of the effect of globalization on the employment rate of women in the four regions of Africa, namely the Central, Eastern, Western and Southern regions for a proper analysis. These results showed a positive and significant effect of trade liberalization in East and Central Africa. This situation can be explained by the fact that trade liberalization allowed the acquisition of new markets and therefore opportunities for women, as they are mostly represented in the informal sector, who's main activity remains trade. Thus, contrary to these two regions (East and Central Africa), the results also showed a negative and significant relationship of FDI which contributes to the reduction of women's employability by about $0.004 \%$ in West Africa. This result can also be explained by the fact that the industries that often set up in developing countries, particularly in Africa, are processing industries that are physically or mechanically intensive. This situation can lead to a greater demand for male than female labor.

The results also showed that for Central and Eastern Africa, a positive and significant effect of GDP contributed to the increase in the female employment rate of about $0.06 \%$ for these two regions. For these same regions, the results showed that the female fertility rate contributes to a reduction in the employment rate of about $0.1 \%$ and $0.2 \%$ respectively for Central and East Africa. In West Africa, the high proportion of young women between the ages of 15 and 64 increased the female employment rate by about $0.06 \%$.

Table 3. Results of estimates of the effect of globalization on the employment rate in SSA regions

\begin{tabular}{lcccc}
\hline \multirow{2}{*}{ Variables } & \multicolumn{3}{c}{ Estimation by the GMM estimator } \\
\cline { 2 - 5 } L.PAF & Center & East & West & South \\
Trade & $0.908^{* * *}$ & $0.895^{* * *}$ & $0.931^{* * *}$ & $0.809^{* * *}$ \\
& $(0.016)$ & $(0.015)$ & $(0.008)$ & $(0.044)$ \\
FDI & $0.001^{* *}$ & $0.003^{* * *}$ & 0.001 & 0.003 \\
& $(0.000358)$ & $(0.001)$ & $(0.001)$ & $(0.002)$ \\
GDP & -0.0002 & -0.003 & $-0.004 *$ & -0.001 \\
& $(0.000677)$ & $(0.003)$ & $(0.002)$ & $(0.011)$ \\
Pop15-64 Women & $0.064 * * *$ & $0.0593 *$ & -0.002 & 0.175 \\
& $(0.016)$ & $(0.034)$ & $(0.037)$ & $(0.145)$ \\
Urbanization & 0.008 & 0.017 & $0.063 * * *$ & 0.057 \\
& $(0.009)$ & $(0.018)$ & $(0.010)$ & $(0.053)$ \\
Fertility & $-0.009 * *$ & $-0.024 * * *$ & $-0.016 * * *$ & 0.011 \\
& $(0.004)$ & $(0.009)$ & $(0.005)$ & $(0.009)$ \\
Constant & $-0.113 * * *$ & $-0.176^{* * *}$ & -0.015 & -0.086 \\
& $(0.024)$ & $(0.057)$ & $(0.045)$ & $(0.212)$ \\
Observations & $5.439^{* * *}$ & $6.021 * * *$ & 0.401 & 3.672 \\
Number of Id & $(0.647)$ & $(1.243)$ & $(0.684)$ & $(2.419)$ \\
\hline
\end{tabular}

Standard errors in parentheses

$* * * \mathrm{p}<0.01, * * \mathrm{p}<0.05, * \mathrm{p}<0.1$ 


\section{Conclusion and Policy Implications}

This work which allowed us to analyse the impact of globalization on women's employability in Sub-Saharan Africa, measured by trade liberalization and FDI, was studied from 1995 to 2018. The panel model is employed in the econometric method, and the GMM estimator is used to obtain unbiased findings. The empirical findings showed that the degree of trade openness in Sub-Saharan African countries has a beneficial impact on women's employment rates. When globalization is measured in terms of FDI, however, the effect is the polar opposite. Women's employability in these areas is harmed by the significant concentration of heavy or processing businesses that require physical labor. The favorable impact of globalization's social and economic dimensions on women's economic empowerment, on the other hand, suggested that opening up trade in products has a positive impact on improving women's social status and, as a result, lessening their victimization by male dominance.

As a policy implication, SSA countries needed to make policies that can enhance free trade and promote trade openness. There is a need for SSA countries to strengthen efforts towards women's empowerment and give opportunities for women's employment policies and programs to effectively reduce poverty.

\section{Acknowledgements}

We sincerely thank Professor Agbodji Ega Akoete, lecturer in Economics at the University of Lome for his encouragement and humility in helping us for our academic grade. Receive the blessing of the almighty God.

\section{References}

Arellano, M., \& Bond, S. (1991). Some tests of specification for panel data: Monte Carlo evidence and an application to employment equations. The Review of Economic Studies, 58(2), 277-297. https://doi.org/10.2307/2297968

Asongu, S. A., \& Odhiambo, N. M. (2018). ICT, financial access and gender inclusion in the formal economic sector: Evidence from Africa. African Finance Journal, 20(2), 45-65. https://doi.org/10.2139/ssrn.3305000

Asongu, S. A., \& Odhiambo, N. M. (2019). Challenges of doing business in Africa: A systematic review. Journal of African Business, 20(2), 259-268. https://doi.org/10.1080/15228916.2019.1582294

Asongu, S. A., Efobi, U. R., Tanankem, B. V., \& Osabuohien, E. S. (2020). Globalisation and female economic participation in Sub-Saharan Africa. Gender Issues, 37(1), 61-89. https://doi.org/10.1007/s12147-019-09233-3

Becker, G. S. (1964). Human capital: A theoretical and empirical analysis, with special reference to education (SSRN Scholarly Paper No. ID 1496221). Rochester, NY: Social Science Research Network.

Braunstein, E. (2006). Foreign direct investment, development and gender equity: A review of research and policy. Occasional Paper No.12. Geneva: United Nations Research Institute for Social Development.

Chant, S., \& Nikki, C. (2003). Gender in Latin America. New Brunswick, NJ: Rutgers University Press. https://doi.org/10.3362/9781909013209

Edon, C., \& Kamionka, T. (2011). Dynamic modeling of fertility and labor force participation of women in couples. Economics Review, 62(3), 429-440. http://hdl.handle.net/2078.1/163660

Efobi, U. R., Tanankem, B. V., \& Asongu, S. A. (2018). Female economic participation with information and communication technology advancement: Evidence from Sub-Saharan Africa. South African Journal of Economics, 86(2), 231-246. https://doi.org/10.1111/saje.12194

Elu, J. U., \& Loubert, L. (2013). Earnings inequality and the intersectionality of gender and ethnicity in Sub-Saharan Africa: The case of Tanzanian manufacturing. American Economic Review, 103(3), 289-292. https://doi.org/10.1257/aer.103.3.289

Faggian, A. (2014). Job search theory. In Fischer, M.M., Nijkamp, P. (Eds.), Handbook of Regional Science (pp. 59-73). Berlin, Heidelberg: Springer. https://doi.org/10.1007/978-3-642-23430-9_8

Gray, M. M., Kittilson, M. C., \& Sandholtz, W. (2006). Women and globalization: A study of 180 countries, 1975-2000. International Organization, 60(2), 293-333. https://doi.org/10.1017/s0020818306060176

Hazel, M. M. (2010). Poverty among women in Sub-Saharan Africa: A review of selected issues. Journal of International Women's Studies, 11(4), 50-72.

Hirata, H., \& Le Doaré, H. (1998). The paradoxes of globalization, notebooks Gedisst, n²1.

Katz, E. (2003). Gender and Ejido Reform, Draft Report prepared for the World Bank Ejido Study, january 21.

Lachaud, J. P. ( 2008). Poverty, Labour Market and Pro-poor Growth in Madagascar. Book, International Labour Office

Lim, Y. J. (2000). The effect of East Asian crisis on the employment of women and men : the Philippine case. World 
Development, 28(7). https://doi.org/10.1016/S0305-750X(00)00023-1

Marquez, B. A. (2017). The effects of hacienda culture on the gendered division of labor within the Charro Community. Gender Issues, 34(1), 3-22. https://doi.org/10.1007/s12147-016-9160-y

Moghadam, V. M. (1999). Gender and globalization: Female labor and women's mobilization. Journal of World-Systems Research, 5(2), 367-388. https://doi.org/10.5195/jwsr.1999.139

Nkurunziza, M. (2018). "Sub-Saharan Africa, losing $\$ 2.5$ trillion due to gender inequality - World Bank", The New Times. Retrieved January 1, 2018, from https://www.newtimes.co.rw/business/sub-saharan-africa-losing-25-trillion-due-gender-inequality-world-bank

Osabuohien, E. S., Efobi, U. R., Herrmann, R. T., \& Gitau, C. M. (2019). Female labor outcomes and large-scale agricultural land investments: Macro-micro evidencefrom Tanzania. Land Use Policy, 82, 716-728. https://doi.org/10.1016/j.landusepol.2019.01.005

Pacaut, P., Le Bourdais, C., \& Laplante, B. (2007). Dynamics and Determinants of Women's Labour Force Participation after Childbirth in Canada. Quebec demographics Notebooks, 36(2), 249-279. https://doi.org/10.7202/029625ar

Parida, J. (2011). Globalisation and its Impact on Women - an assessment. The Indian Journal of Political Science, 72(2), Indian Political Science Association, 429-35. Retrieved from http://www.jstor.org/stable/42761428

Rice, L., \& Barth, J. M. (2017). A tale of two gender roles: The effects of implicit and explicit gender role traditionalism and occupational stereotype on hiring decisions. Gender Issues, 34(1), 86-102.

https://doi.org/10.1007/s12147-016-9175-4

Rioux, L. (2001). Reserve salary, declining unemployment benefit and minimum integration income. Economics and Statistics, 346(1), 137-160. https://doi.org/10.3406/estat.2001.7437

Schultz, T. W. (1961). Investment in human capital. The American Economic Review, 51(1), 1-17.

Stephan, G. (2014). Permanent and transient shocks in unemployment and GDP: Germany versus European countries. Political Economy Journal, 124(5), 789-815. https://doi.org/10.3917/redp.245.0789

Talahite, F. (1998). Algeria, Female Employment in Transition, European University Institute Robert Schuman Centre for Advanced Studies Mediterranean Programme, Eight Mediterranean Social and Political Research Meeting Florence - Montecatini Terme, 21-25 March 2007.

Thevenon, O. (2004). The challenges for female employment of the European employment strategy. OFCE Review, 3(90), 379-417. Retrieved from https://www.cairn.info/revue-de-1-ofce-2004-3-page-379.htm

Treillet, S. (1999). The regression of salaried employment: myth or reality? The case of peripheral countries», The Infernal Triangle, Crisis, globalization, financialization, Dumenil Gérard et Levy Dominique (dir.), current Marx/Confrontation, PUF, 1999.

Uduji, J., \& Okolo-Obasi, E. (2018a). Does corporate social responsibility (CSR) impact on development of women in small-scale fisheries of Sub-Saharan Africa? Evidence from coastal communities of Niger Delta in Nigeria: African Governance and Development Institute ( AGDI), Working papers No. WP/18/059.

Uduji., J. I., \& Okolo-Obasi, E. N. (2019b). Corporate social responsibility initiatives in Nigeria and rural women livestock keepers in oil host communities. Social Responsibility Journal, 15(8), 1008-1032. https://doi.org/10.1108/srj-01-2018-0025

Uduji.., J. I., \& Okolo-Obasi, E. N. (2018). Young rural women's participation in the e-wallet programme and usage intensity of modern agricultural inputs in Nigeria. Gender, Technology and Development, 22(1), 59-81. https://doi.org/10.1080/09718524.2018.1445894

Villarreal, A., \& Yu, W. (2007). Economic globalization and women's employment: The case of manufacturing in Mexico. American Sociological Review, 72(3), 365-389. https://doi.org/10.1177/000312240707200303

WDI. (2019). https://databank.worldbank.org/source/World-development-indicators,2019

Zajdela, H. (1990). The dualism of the labor market: Issues and theoretical foundations" Economics and Forecasting, Perseus National Program, 92(1), 31-42. Handle: RePEc:prs:ecoprv:ecop_0249-4744_1990_num_92_1_5155

\section{Copyrights}

Copyright for this article is retained by the author(s), with first publication rights granted to the journal.

This is an open-access article distributed under the terms and conditions of the Creative Commons Attribution license which permits unrestricted use, distribution, and reproduction in any medium, provided the original work is properly cited. 